\title{
ZRÓŻNICOWANIE SYTUACJI FINANSOWEJ SPÓŁDZIELNI MLECZARSKICH W POLSCE
}

\author{
Teresa Domańska, Tomasz Felczak \\ Katedra Finansów \\ Szkoła Główna Gospodarstwa Wiejskiego w Warszawie
}

\begin{abstract}
Abstrakt. W opracowaniu przedstawiono zróżnicowanie sytuacji finansowej spółdzielni mleczarskich w Polsce. W celu określenia sytuacji tych podmiotów wykorzystano wskaźniki płynności finansowej, skorygowanej rentowności, zadłużenia oraz sprawności działania. Okres badań obejmował lata 2010-2014. Bez względu na koniunkturę gospodarczą na rynku, zarządzający zachowywali ostrożność w celu uniknięcia ryzyka, które mogło wpływać na zdolność jednostki do kontynuacji działalności. Zróżnicowanie sytuacji finansowej spółdzielni mleczarskich było stosunkowo duże. Zarówno efektywność jak i struktura finansowania uzależniona była od skali i warunków prowadzonej działalności.
\end{abstract}

Słowa kluczowe: płynność finansowa, skorygowana rentowność, zadłużenie, sprawność działania, spółdzielnia mleczarska, sytuacja finansowa

\section{WSTĘP}

Szczególną formą gospodarki żywnościowej jest spółdzielnia, która posiada dwoisty charakter [Zuba 2009, s. 167]. Z punktu widzenia organizacyjnego spółdzielnia jest dobrowolnym zrzeszeniem nieograniczonej liczby osób, którego skład osobowy oraz fundusz udziałowy może ulegać zmianie [Ustawa z dnia 16 września 1982 r., s. 1]. Powszechnie przyjmuje się, że działalność gospodarcza prowadzona $\mathrm{w}$ formie spółdzielni opierana jest na odrębnych zasadach, tzw. zasadach spółdzielczych [Pietrzak 2006, s. 31]. Spółdzielnia mleczarska w interesie członków prowadzi wspólną działalność gospodarczą. Obok działalności gospodarczej spółdzielnia może również prowadzić działalność społeczną i oświatowo- 
kulturalną na rzecz swoich członków i ich środowiska. Jednakże z drugiej strony spółdzielnia mleczarska jednocześnie prowadzi działalność gospodarczą, a zatem z punktu widzenia rachunku ekonomicznego jest również przedsiębiorstwem produkcyjnym [Dworniak 2010, s. 9].

Doświadczenia wielu krajów wskazują na dużą żywotność i efektywność ekonomiczną spółdzielczych form działalności ze szczególnym uwzględnieniem agrobiznesu [Kata 2016, s. 84]. Spółdzielcza forma działalności gospodarczej pomimo zmniejszenia liczby podmiotów nadal odgrywa ważną rolę i jest jedną z wiodących branż w całej gospodarce żywnościowej [Chmielewska, Mądra 2008, s. 60]. Jedną z ważniejszych sfer agrobiznesu w Polsce, w których spółdzielcza forma własności odgrywa istotną rolę jest przetwórstwo mleka [Pietrzak 2010, s. 172]. Sektor mleczarski należy do branż rozproszonych o stosunkowo niewielkiej przeciętnej wielkości przedsiębiorstw. Mimo zwiększenia procesów koncentracji w branży, przeciętna wielkość tych podmiotów w Polsce jest znacznie mniejsza od światowych liderów [Pietrzak 2007, s. 107]. Produkcja mleka krowiego w Polsce w 2014 roku wyniosła 12976 tys. ton, co stanowiło 2\% produkcji światowej [GUS 2016, s. 406]. Zagospodarowanie tak znaczącej produkcji rolniczej wymaga zaangażowania dużych mocy produkcyjnych szczególnie w przypadku mleka surowego, którego termin przydatności jest wyjątkowo krótki. Pod tym względem spółdzielnie mleczarskie odgrywają zasadniczą rolę, realizując np. w 2014 roku skup produktów rolnych na kwotę 9 213,3 mln zł [GUS 2016, s. 266].

Biorąc pod uwagę nieco odmienne cele i uwarunkowania działalności oraz szerokie grono interesariuszy, ocena działalności spółdzielni mleczarskich nabiera dużego znaczenia. Zapewnienie ciągłości działania spółdzielni mleczarskich, w odróżnieniu do większości przedsiębiorstw, nie sprowadza się jedynie do stabilności zatrudnienia w tych podmiotach. W przypadku spółdzielni równie istotne jest zapewnienie rynków zbytu dla dostawców, którzy zarazem są członkami spółdzielni. Dlatego badanie sytuacji finansowej w spółdzielniach mleczarskich stanowi ważne zagadnienie od strony ekonomicznej, jak również społecznej.

Dotychczasowe badania z zakresu oceny sytuacji finansowej spółdzielni mleczarskich realizowane były m.in. przez Dworniaka [2010], Pietrzaka [2006], Wasilewskiego, Chmielewską [2006], Baran [2008], Zubę i Zubę [2011], Chądrzyńskiego i Nowak [2014] oraz Domańską [2016].

\section{METODY BADAŃ}

Celem opracowania jest przedstawienie zróżnicowania sytuacji finansowej spółdzielni mleczarskich w Polsce, za pomocą wskaźników płynności finansowej, skorygowanej rentowności, zadłużenia i sprawności działania. 
TABELA 1. Formuły obliczenia wybranych wskaźników do badania

\begin{tabular}{|c|c|}
\hline Wyszczególnienie & Formuła \\
\hline \multicolumn{2}{|c|}{ Wskaźniki płynności finansowej } \\
\hline \multirow[t]{2}{*}{ Wskaźnik bieżącej płynności } & aktywa obrotowe \\
\hline & zobowiązania krótkoterminowe \\
\hline \multirow{2}{*}{ Wskaźnik płynności przyspieszonej } & aktywa obrotowe - zapasy \\
\hline & $\overline{\text { zobowiązania krótkoterminowe }}$ \\
\hline \multirow{2}{*}{ Wskaźnik płynności natychmiastowej } & inwestycje krótkoterminowe \\
\hline & $\overline{\text { zobowiązania krótkoterminowe }}$ \\
\hline \multicolumn{2}{|c|}{ Wskaźniki skorygowanej rentowności } \\
\hline \multirow{2}{*}{$\begin{array}{l}\text { Wskaźnik skorygowanej rentowności } \\
\text { aktywów }\end{array}$} & zysk netto + wpływy netto z wydania udziałów \\
\hline & $\begin{array}{c}\text { aktywa } \\
\end{array}$ \\
\hline \multirow{2}{*}{$\begin{array}{l}\text { Wskaźnik skorygowanej rentowności } \\
\text { funduszu własnego }\end{array}$} & zysk netto + wpływy netto z wydania udziałów \\
\hline & $\begin{array}{l}\text { fundusz własny } \\
\end{array}$ \\
\hline \multirow{2}{*}{$\begin{array}{l}\text { Wskaźnik skorygowanej rentowności } \\
\text { przychodów }\end{array}$} & zysk netto + wpływy netto z wydania udziałów \\
\hline & przychody ze sprzedaży \\
\hline \multicolumn{2}{|c|}{ Wskaźniki zadłużenia } \\
\hline \multirow{2}{*}{ Wskaźnik zadłużenia ogółem } & zobowiązania ogółem \\
\hline & $\overline{\text { aktywa ogółem }}$ \\
\hline \multirow{2}{*}{ Wskaźnik zadłużenia funduszu własnego } & zobowiązania ogółem \\
\hline & $\overline{\text { fundusz własny }}$ \\
\hline \multirow{2}{*}{ Wskaźnik zadłużenia długoterminowego } & zobowiązania długoterminowe \\
\hline & fundusz własny \\
\hline \multicolumn{2}{|c|}{ Wskaźniki sprawności działania } \\
\hline \multirow{2}{*}{ Wskaźnik cyklu zapasów } & średni stan zapasów $\times 365$ \\
\hline & koszty operacyjne ${ }^{3}$ \\
\hline Wskaźnik cyklu należności & $\frac{\text { średni stan należności }}{\text { przychodv ze sprzedaży }} \times 365$ \\
\hline Wskaźnik cyklu zobowiązań & $\frac{\text { średni stan zobowiązań }}{\text { koszty operacyjne }} \times 365$ \\
\hline
\end{tabular}

Źródło: Opracowanie własne.

Badaniami objęto 68 spółdzielni mleczarskich, które w latach 2010-2014 nieprzerwanie prowadziły działalność gospodarczą. Wybrane spółdzielnie podlegały badaniu ${ }^{1}$ i ogłaszaniu sprawozdań finansowych. Źródłowe dane spółdzielni mle-

${ }^{1}$ Na podstawie art. 88a. § 1. ustawy z dnia 16 września 1982 r. Prawo Spółdzielcze, Dz.U. $\mathrm{Nr} 30$ poz. 210., roczne sprawozdania finansowe spółdzielni podlegają badaniu pod 
czarskich zakwalifikowanych do badania, pochodziły z jednostkowych, rocznych sprawozdań finansowych, które zgodnie z ustawą o rachunkowości [Ustawa z dnia 29 września 1994 r.] zostały opublikowane w Monitorze Spółdzielczym B². W celu przeprowadzenia badań założono, iż zakwalifikowane spółdzielnie mleczarskie wykazywały na koniec każdego roku zobowiązania krótkoterminowe.

Przeprowadzone badania miały charakter analizy sektorowej. Ocena zróżnicowania sytuacji finansowej spółdzielni mleczarskich wymagała przyjęcia do badania odpowiednich wskaźników finansowych. Wybrane wskaźniki do przeprowadzenia badań oraz formuły ich obliczenia zaprezentowano w tabeli 1 .

W celu określenia sytuacji finansowej spółdzielni mleczarskich w opracowaniu wykorzystano wskaźniki płynności finansowej, skorygowanej rentowności ${ }^{3}$, zadłużenia oraz sprawności działania.

\section{WYNIKI BADAŃ}

W tabeli 2 przedstawiono podstawowe statystyki opisowe ${ }^{4}$ zróżnicowania wskaźników płynności finansowej spółdzielni mleczarskich w latach 2010-2014. Średni poziom wskaźnika bieżącej płynności finansowej w spółdzielniach mleczarskich w latach 2010-2014 kształtował się w przedziale od 1,7 do 2,0. Oznacza to, że aktywa obrotowe pokrywały zobowiązania bieżące w $170-200 \%$, tj. na poziomie uznanym za bezpieczny. Na podstawie analizy wskaźnika zmienności $(\mathrm{v}=$ = 38,3-54,1\%) stwierdzono, iż badane spółdzielnie mleczarskie były we wszyst-

względem rzetelności i prawidłowości, (§ 2.) w trybie i według zasad określonych w odrębnych przepisach.

2 Na podstawie art. 14. ustawy z dnia 16 września 1982 r. Prawo Spółdzielcze, Dz. U. Nr 30 poz. 210., organem właściwym do publikowania ogłoszeń spółdzielczych przewidzianych w przepisach prawa jest „Monitor Spółdzielczy” wydawany przez Krajową Radę Spółdzielczą, z wyjątkiem ogłoszeń zamieszczanych na podstawie odrębnych przepisów w Monitorze Sądowym i Gospodarczym.

${ }^{3}$ Wskaźniki skorygowanej rentowności obliczono jako relację sumy zysku netto i wpłat na fundusz udziałowy do wartości aktywów ogółem, funduszu własnego oraz przychodów ze sprzedaży. Suma wpłat na fundusz udziałowy w danym roku stanowiła dodatkową nadwyżkę środków pieniężnych. Wskaźniki te precyzyjniej odzwierciedlały specyfikę działalności spółdzielni mleczarskich od klasycznych wskaźników rentowności [Wasilewski, Dworniak 2007, s. 123].

${ }^{4}$ Statystyki te opisują analizowane zjawisko na przykładzie sektora mleczarskiego. W badaniu uwzględniono podstawowe miary położenia, zmienności i asymetrii, umożliwiające określenie właściwości rozkładów empirycznych poszczególnych cech, tj. średnią arytmetyczną $(\overline{\mathrm{x}})$, minimum $\left(\mathrm{x}_{\min }\right)$, maksimum $\left(\mathrm{x}_{\max }\right)$, kwartyl $1\left(\mathrm{Q}_{1}\right)$, kwartyl 2 czyli medianę $\left(Q_{2}\right)$, kwartyl $3\left(Q_{3}\right)$, odchylenie standardowe $(\sigma)$ i współczynnik zmienności $(v)$. 
kich latach silnie zróżnicowane pod względem poziomu płynności bieżącej. Współczynnik skośności wskaźnika płynności bieżącej, określający asymetrię rozkładu analizowanej zmiennej mieścił się w przedziale $0,9-1,9$, co świadczyło o prawo skośnym rozkładzie $\left(\bar{x}>Q_{2}\right)$. Oznacza to, że $w$ ponad połowie badanych jednostek płynność bieżąca była niższa od średniej z całej badanej populacji. Wskaźnik bieżącej płynności finansowej kształtował się poniżej 1,2-1,3 w 25\% badanych spółdzielniach mleczarskich (tj. 1,2 w 2010 roku i 2013 roku oraz 1,3 dla lat 2011-2012 i 2014 roku). Natomiast w 75\% populacji wskaźnik ten znajdował się powyżej wymaganego poziomu 1,2-1,3, który zapewniał zdolność przedsiębiorstwa do terminowego regulowania zobowiązań. W połowie badanych spółdzielni mleczarskich utrzymywano wskaźnik bieżącej płynności poniżej 1,6-1,7 (odpowiednio w latach 2010-2011 oraz 2012-2014), natomiast w drugiej połowie badanych jednostek powyżej wskazanego poziomu. Ponadto w badanym okresie zarządzający przeciętnie 17 spółdzielniami utrzymywali nadpłynność w porównaniu do innych podmiotów (tj. średnio 2,1-2,2). W latach 2010-2014 stwierdzono wzrost poziomu wskaźnika bieżącej płynności przeciętnie o 0,3 (średnio 1,7 w 2010 roku oraz 2,0 w 2014 roku).

W latach 2010-2014 w badanej grupie spółdzielni mleczarskich, zarządzający kształtowali wskaźnik płynności przyśpieszonej przeciętnie w przedziale 1,3-1,5. Po wyeliminowaniu wpływu zapasów, płynne aktywa obrotowe nadal pokrywały zobowiązania bieżące. Mogło to wskazywać na konserwatywne podejście zarządzających do zachowania płynności finansowej. Podobnie jak w przypadku wskaźnika bieżącej płynności, rozkład wskaźnika płynności przyśpieszonej cechowała asymetria prawostronna $\left(\bar{x}>Q_{2}\right)$. Oznacza to, że w ponad połowie badanych spółdzielni mleczarskich płynność przyśpieszona była niższa od średniej dla całej grupy. Zróżnicowanie tych spółdzielni pod względem poziomu wskaźnika przyśpieszonej płynności było wyraźnie silniejsze, niż według kategorii płynności bieżącej. Wskazuje na to analiza współczynnika zmienności, który dla tej miary płynności mieścił się w przedziale $V=43,6-59,4 \%$, wykazując przy tym wyraźną tendencję wzrostową.

Badana grupa spółdzielni najsilniej zróżnicowana była pod względem poziomu płynności natychmiastowej. W latach 2010-2014 przeciętnie najbardziej płynne aktywa obrotowe pokrywały zobowiązania bieżące w stabilnym przedziale 40-60\%. Jednakże współczynnik zmienności dla tego wskaźnika był bardzo wysoki i kształtował się w granicach od 107,5 do 125,9\%. Silną dyspersję tej kategorii płynności potwierdzają również pozostałe statystyki opisowe. Podobnie jak w przypadku pozostałych wskaźników płynności, należy stwierdzić asymetrię prawostronną $\left(\overline{\mathrm{x}}>\mathrm{Q}_{2}\right)$. Oznacza to, że w ponad połowie badanych jednostek poziom natychmiastowej płynności finansowej w badanych latach był niższy od średniej dla całej grupy spółdzielni mleczarskich. 
TABELA 2. Statystyki opisowe zróżnicowania wskaźników płynności finansowej

\begin{tabular}{|c|c|c|c|c|c|c|c|c|c|}
\hline \multicolumn{2}{|l|}{ Wyszczególnienie } & \multicolumn{8}{|c|}{ Statystyki opisowe* } \\
\hline Zmienna & Lata & $\mathrm{x}_{\min }$ & $\overline{\mathrm{x}}$ & $\mathrm{X}_{\max }$ & $\mathrm{Q}_{1}$ & $\mathrm{Q}_{2}$ & $\mathrm{Q}_{3}$ & $\sigma$ & V \\
\hline \multirow{5}{*}{$\begin{array}{l}\text { Wskaźnik bieżącej } \\
\text { płynności }\end{array}$} & 2010 & 0,6 & 1,7 & 3,7 & 1,2 & 1,6 & 2,1 & 0,7 & 41,9 \\
\hline & 2011 & 0,7 & 1,7 & 3,7 & 1,3 & 1,6 & 2,1 & 0,7 & 38,3 \\
\hline & 2012 & 0,8 & 1,8 & 4,8 & 1,3 & 1,7 & 2,2 & 0,8 & 42,0 \\
\hline & 2013 & 0,8 & 1,8 & 4,5 & 1,2 & 1,7 & 2,1 & 0,7 & 40,2 \\
\hline & 2014 & 0,6 & 2,0 & 6,0 & 1,3 & 1,7 & 2,2 & 1,1 & 54,1 \\
\hline \multirow{5}{*}{$\begin{array}{l}\text { Wskaźnik } \\
\text { przyśpieszonej } \\
\text { płynności }\end{array}$} & 2010 & 0,2 & 1,3 & 3,3 & 0,8 & 1,2 & 1,6 & 0,6 & 49,5 \\
\hline & 2011 & 0,3 & 1,3 & 3,4 & 0,9 & 1,1 & 1,7 & 0,6 & 43,6 \\
\hline & 2012 & 0,1 & 1,4 & 4,0 & 1,0 & 1,3 & 1,8 & 0,7 & 48,1 \\
\hline & 2013 & 0,5 & 1,4 & 3,8 & 1,0 & 1,3 & 1,7 & 0,7 & 46,5 \\
\hline & 2014 & 0,1 & 1,5 & 4,2 & 0,9 & 1,3 & 1,8 & 0,9 & 59,4 \\
\hline \multirow{5}{*}{$\begin{array}{l}\text { Wskaźnik } \\
\text { natychmiastowej } \\
\text { płynności }\end{array}$} & 2010 & 0,0 & 0,4 & 2,6 & 0,1 & 0,3 & 0,6 & 0,6 & 125,2 \\
\hline & 2011 & 0,0 & 0,4 & 2,6 & 0,0 & 0,2 & 0,7 & 0,5 & 121,4 \\
\hline & 2012 & 0,0 & 0,5 & 2,9 & 0,1 & 0,3 & 0,7 & 0,6 & 117,3 \\
\hline & 2013 & 0,0 & 0,6 & 3,1 & 0,1 & 0,4 & 0,8 & 0,6 & 107,5 \\
\hline & 2014 & 0,0 & 0,6 & 3,5 & 0,0 & 0,3 & 0,8 & 0,8 & 125,9 \\
\hline
\end{tabular}

*Statystyki opisowe: $x_{\min }-$ minimum, $x_{\max }-$ maksimum, $\bar{x}$ - średnia arytmetyczna, $Q_{1}-$ kwartyl $1, Q_{2}-$ - kwartyl 2 (mediana), $Q_{3}$ - kwartyl 3, $\sigma$-odchylenie standardowe, v- współczynnik zmienności.

Źródło: opracowanie własne.

Zarządzający spółdzielniami mleczarskimi w latach 2010-2014 utrzymywali przeciętnie wystarczający poziom wskaźników, zarówno bieżącej, jak i przyśpieszonej płynności. Ponadto w 25\% badanych spółdzielni utrzymywano wskaźnik płynności natychmiastowej w granicach od 0,6 do 0,8, co mogło świadczyć o pokryciu ponad połowy zobowiązań bieżących przez inwestycje krótkoterminowe. W badanych latach zarządzający zwiększali poziom wszystkich miar płynności finansowej, na co mogło mieć wpływ kilka czynników. Na zróżnicowanie płynności finansowej w spółdzielniach mleczarskich mogły mieć wpływ czynniki makroekonomiczne. Jednak za główne czynniki należy uznać przede wszystkim przyjęte, przez zarządzających spółdzielniami, strategie finansowe, które mogły przesądzić o poziomach różnych relacji majątkowo-kapitałowych będących indykatorami płynności.

Statystyki opisowe zróżnicowania wskaźników skorygowanej rentowności spółdzielni mleczarskich w latach 2010-2014 przedstawiono w tabeli 3. Średni poziom wskaźnika skorygowanej rentowności funduszu własnego w spółdzielniach mleczarskich w latach 2010-2014 kształtował się w przedziale od 0,3\% do 
10,8\%. Na podstawie analizy wskaźnika zmienności (V=65,9-3350,0\%) stwierdzono, iż badane spółdzielnie mleczarskie były we wszystkich latach silnie zróżnicowane pod względem skorygowanej rentowności funduszu własnego. W roku 2014 stwierdzono najsilniejsze zróżnicowane spółdzielni mleczarskich pod względem tego wskaźnika.

W latach 2010-2014 mediana wskaźnika skorygowanej rentowności kształtowała się na nieznacznie niższym od średniej dla całej populacji poziomie (tj. $1,9 \%$ do 10,5\%). Wskaźnik skorygowanej rentowności dla 25\% badanych spółdzielni mleczarskich przyjmował wielkości poniżej -4,4\% w 2014 roku do 4,7\% w 2010 roku. Natomiast w 75\% spółdzielni mleczarskich wskaźnik skorygowanej rentowności funduszu własnego kształtował się powyżej najniższego poziomu (odpowiednio 14,4\% w 2013 roku i 6,3\% w 2014 roku).

Wskaźnik skorygowanej rentowności aktywów spółdzielni mleczarskich kształtował się w przedziale od 0,2 \% w 2014 roku do 6,1\% w 2013 roku. W połowie badanych spółdzielni mleczarskich wskaźnik skorygowanej rentowności kształtował się poniżej 1,1\% (w 2014 roku) do 5,2\% (w 2013 roku).

Wskaźnik skorygowanej rentowności przychodów ze sprzedaży kształtował się na średnim poziomie od $0,2 \%$ do $2,4 \%$. Najwyższy poziom, tj. $10 \%$ wskaźnika skorygowanej rentowności przychodów ze sprzedaży odnotowano w 2013 roku.

W spółdzielniach mleczarskich w latach 2010-2012 wszystkie wskaźniki skorygowanej rentowności ulegały obniżeniu. W 2013 roku wskaźniki skorygowanej rentowności osiągnęły najwyższy poziom w całym okresie badawczym (odpowiednio dla poszczególnych wskaźników: 10,8\%, 6,1\%, 2,4\%). Najniższe wyniki finansowe spółdzielnie mleczarskie osiągnęły w 2014 roku, co przełożyło się na niższą skorygowaną rentowność funduszu własnego, aktywów oraz przychodów ze sprzedaży (tj. 0,3\%, 0,2\% oraz 0,2\%).

W tabeli 4 zaprezentowano statystyki opisowe zróżnicowania wskaźników zadłużenia spółdzielni mleczarskich. W latach 2010-2014 średni poziom wskaźnika zadłużenia ogółem spółdzielni mleczarskich wahał się w granicach od 44,0\% do 47,7\%. Współczynnik zmienności wskaźnika zadłużenia ogółem spółdzielni mleczarskich (V = 26,1\%-30,3\%) wskazywał na umiarkowane zróżnicowane. Natomiast w badanej populacji rozkład poziomu wskaźnika zadłużenia ogółem był prawostronnie asymetryczny $\left(\bar{x}>Q_{2}\right)$, co oznacza, że w analizowanych latach w ponad połowie jednostek zadłużenie ogółem było niższe od średniej z całej populacji.

Minimalne przeciętne zadłużenie $\mathrm{w}$ grupie kształtowało się na poziomie od 22,4\% w 2010 roku do 15,8\% w 2014 roku. Maksymalny poziom zadłużenia ogółem w spółdzielniach mleczarskich wyniósł 77\% w 2013 roku. Jednakże w 75\% badanych spółdzielni mleczarskich utrzymywano przeciętny wskaźnik zadłużenia ogółem w granicach od 53,4\% do 56,3\%. Oznacza to, że zarządzający spółdziel- 
TABELA 3. Statystyki opisowe zróżnicowania wskaźników skorygowanej rentowności [\%]

\begin{tabular}{|c|c|c|c|c|c|c|c|c|c|}
\hline \multicolumn{2}{|l|}{ Wyszczególnienie } & \multicolumn{8}{|c|}{ Statystyki opisowe* } \\
\hline Zmienna & Lata & $\mathrm{x}_{\min }$ & $\overline{\mathrm{x}}$ & $\mathrm{x}_{\max }$ & $\mathrm{Q}_{1}$ & $\mathrm{Q}_{2}$ & $Q_{3}$ & $\sigma$ & V \\
\hline \multirow{5}{*}{$\begin{array}{l}\text { Wskaźnik } \\
\text { skorygowanej } \\
\text { rentowności funduszu } \\
\text { własnego } \\
\text { Skor. ROE }\end{array}$} & 2010 & 0,1 & 9,9 & 26,3 & 4,7 & 8,7 & 13,6 & 6,6 & 65,9 \\
\hline & 2011 & $-15,6$ & 8,5 & 25,1 & 4,3 & 8,0 & 11,7 & 6,9 & 82,1 \\
\hline & 2012 & $-17,8$ & 6,1 & 24,2 & 2,3 & 6,7 & 9,9 & 7,1 & 115,3 \\
\hline & 2013 & $-9,9$ & 10,8 & 38,0 & 4,3 & 10,5 & 14,4 & 8,8 & 81,6 \\
\hline & 2014 & $-24,3$ & 0,3 & 27,9 & $-4,4$ & 1,9 & 6,3 & 9,4 & 3350,0 \\
\hline \multirow{5}{*}{$\begin{array}{l}\text { Wskaźnik } \\
\text { skorygowanej } \\
\text { rentowności aktywów } \\
\text { Skor. ROA }\end{array}$} & 2010 & 0,0 & 5,3 & 17,2 & 2,5 & 4,7 & 7,5 & 3,8 & 71,4 \\
\hline & 2011 & $-5,5$ & 4,6 & 17,4 & 2,0 & 4,1 & 6,7 & 4,0 & 86,1 \\
\hline & 2012 & $-10,4$ & 3,3 & 13,2 & 1,1 & 3,5 & 5,6 & 3,7 & 112,6 \\
\hline & 2013 & $-6,0$ & 6,1 & 26,8 & 2,2 & 5,2 & 8,6 & 5,5 & 91,2 \\
\hline & 2014 & $-19,1$ & 0,2 & 15,5 & $-2,4$ & 1,1 & 3,4 & 5,5 & 2431,2 \\
\hline \multirow{5}{*}{$\begin{array}{l}\text { Wskaźnik } \\
\text { skorygowanej } \\
\text { rentowności } \\
\text { przychodów } \\
\text { Skor. ROS }\end{array}$} & 2010 & 0,0 & 2,2 & 8,4 & 1,0 & 1,6 & 3,0 & 1,8 & 81,5 \\
\hline & 2011 & $-2,1$ & 1,8 & 7,9 & 0,8 & 1,5 & 2,6 & 1,7 & 89,9 \\
\hline & 2012 & $-4,4$ & 1,3 & 6,0 & 0,4 & 1,4 & 2,0 & 1,5 & 117,0 \\
\hline & 2013 & $-2,2$ & 2,4 & 10,0 & 0,7 & 1,8 & 3,6 & 2,3 & 94,5 \\
\hline & 2014 & $-6,3$ & 0,2 & 6,2 & $-0,8$ & 0,4 & 1,2 & 2,0 & 1030,9 \\
\hline
\end{tabular}

*Statystyki opisowe: $\mathrm{x}_{\min }$ - minimum, $\mathrm{x}_{\max }$ - maksimum, $\overline{\mathrm{x}}$ - średnia arytmetyczna, $\mathrm{Q}_{1}-\mathrm{kwartyl} 1$, $\mathrm{Q}_{2}$ - kwartyl 2 (mediana), $\mathrm{Q}_{3}$ - kwartyl 3, $\sigma$ - odchylenie standardowe, $\mathrm{V}$ - współczynnik zmienności.

Źródło: opracowanie własne.

niami kształtowali ten wskaźnik nieco poniżej dolnej granicy umownych norm ${ }^{5}$. Im wyższy poziom wskaźnika, tym wyższy poziom zadłużenia przedsiębiorstwa, a tym samym wyższe ryzyko finansowe. Dlatego zarządzający spółdzielniami mleczarskimi w kształtowaniu poziomu wskaźnika zadłużenia ogółem mogli kierować się minimalizacją ryzyka finansowego w jednostkach.

Przeciętny poziom wskaźnika zadłużenia kapitału własnego charakteryzował się tendencją malejącą, szczególnie w latach 2011-2014. Wówczas zarządzający spółdzielniami zmniejszyli relację kapitału obcego do funduszu własnego średnio o 13,5 pkt.\%. Najniższy przeciętny wskaźnik zadłużenia kapitału własnego wynosił jedynie 18,7\% i wystąpił w 2014 roku. Niektórzy zarządzający znacznie agresywniej finansowali prowadzoną działalność generując zobowiązania ogółem ponad trzykrotnie wyższe od wartości funduszy własnych (tj. 306,5\% w 2011 roku oraz 323,3\% w 2013 roku). Współczynnik zmienności w latach 2010-2014 wykazywał tendencję rosnącą i mieścił się w przedziale od 55,3\% do 60,9\%. Oznacza

${ }^{5}$ Optymalny poziom wskaźnika zadłużenia ogółem znajduje się na poziomie 0,57-0,67. [Sierpińska, Jachna 2004, s. 167]. 
TABELA 4. Statystyki opisowe zróżnicowania wskaźników zadłużenia [\%]

\begin{tabular}{|c|c|c|c|c|c|c|c|c|c|}
\hline \multicolumn{2}{|l|}{ Wyszczególnienie } & \multicolumn{8}{|c|}{ Statystyki opisowe* } \\
\hline Zmienna & Lata & $\mathrm{x}_{\min }$ & $\overline{\mathrm{x}}$ & $\mathrm{x}_{\max }$ & $\mathrm{Q}_{1}$ & $\mathrm{Q}_{2}$ & $\mathrm{Q}_{3}$ & $\sigma$ & $\mathrm{V}$ \\
\hline \multirow{5}{*}{$\begin{array}{l}\text { Wskaźnik } \\
\text { zadłużenia } \\
\text { ogółem }\end{array}$} & 2010 & 22,4 & 47,0 & 74,3 & 38,0 & 45,6 & 56,1 & 12,6 & 26,7 \\
\hline & 2011 & 22,4 & 47,7 & 75,4 & 39,5 & 47,6 & 56,3 & 12,7 & 26,7 \\
\hline & 2012 & 19,6 & 46,4 & 74,5 & 38,3 & 44,9 & 55,8 & 12,9 & 27,7 \\
\hline & 2013 & 21,2 & 46,5 & 76,4 & 38,1 & 46,2 & 54,8 & 12,1 & 26,1 \\
\hline & 2014 & 15,8 & 44,0 & 72,1 & 35,5 & 41,7 & 53,4 & 13,3 & 30,3 \\
\hline \multirow{5}{*}{$\begin{array}{l}\text { Wskaźnik } \\
\text { zadłużenia } \\
\text { funduszu } \\
\text { własnego }\end{array}$} & 2010 & 28,8 & 101,2 & 289,0 & 61,2 & 83,8 & 127,7 & 56,0 & 55,3 \\
\hline & 2011 & 28,8 & 104,3 & 306,5 & 65,2 & 91,0 & 128,8 & 57,6 & 55,3 \\
\hline & 2012 & 24,3 & 99,3 & 292,9 & 62,0 & 81,5 & 126,0 & 56,5 & 56,9 \\
\hline & 2013 & 26,8 & 98,4 & 323,3 & 61,5 & 85,9 & 121,5 & 55,4 & 56,3 \\
\hline & 2014 & 18,7 & 90,8 & 258,0 & 55,0 & 71,5 & 114,8 & 55,3 & 60,9 \\
\hline \multirow{5}{*}{$\begin{array}{l}\text { Wskaźnik } \\
\text { zadłużenia } \\
\text { długoterminowego }\end{array}$} & 2010 & 0,0 & 14,7 & 60,3 & 1,6 & 7,5 & 23,4 & 17,3 & 117,7 \\
\hline & 2011 & 0,0 & 16,3 & 105,3 & 1,5 & 8,3 & 24,5 & 21,0 & 128,7 \\
\hline & 2012 & 0,0 & 15,4 & 116,4 & 0,7 & 9,5 & 22,8 & 21,4 & 139,5 \\
\hline & 2013 & 0,0 & 12,2 & 107,9 & 0,2 & 6,9 & 19,2 & 18,0 & 147,2 \\
\hline & 2014 & 0,0 & 14,1 & 117,2 & 1,0 & 6,2 & 17,5 & 22,7 & 160,9 \\
\hline
\end{tabular}

*Statystyki opisowe: $\mathrm{x}_{\min }-$ minimum, $\mathrm{x}_{\max }-$ maksimum, $\overline{\mathrm{x}}$ - średnia arytmetyczna, $\mathrm{Q}_{1}-$ kwartyl 1 , $\mathrm{Q}_{2}$ - kwartyl 2 (mediana), $\mathrm{Q}_{3}$ - kwartyl 3, $\sigma$ - odchylenie standardowe, $\mathrm{V}$ - współczynnik zmienności.

Źródło: opracowanie własne.

to, że spółdzielnie mleczarskie były silnie zróżnicowanie pod względem poziomu wskaźnika zadłużenia kapitału własnego. Świadczą o tym również pozostałe statystyki opisowe, takie jak odchylenie standardowe (55,3\% - 57,6\%), które wskazuje na dość duży rozrzut poziomu wskaźnika zadłużenia kapitału własnego wokół średniego jego poziomu w populacji.

Rozkład wskaźnika zadłużenia kapitału własnego cechowała asymetria prawostronna $\left(\bar{x}>Q_{2}\right)$. W latach 2010-2014 w ponad połowie badanych spółdzielni mleczarskich wskaźnik zadłużenia kapitału własnego był znacznie niższy od średniej dla całej populacji. Natomiast w 75\% analizowanych spółdzielni wskaźnik ten kształtował się od 114,8\% (w 2014 roku) do 128,8\% (w 2011 roku).

Zarządzający spółdzielniami mleczarskimi utrzymywali poziom zobowiązań długoterminowych od 12,2\% (w 2013 roku) do 16,3\% (w 2011 roku). Niski poziom tego wskaźnika mógł wynikać z bardzo konserwatywnego podejścia zarządzających do zaciągania zobowiązań długoterminowych w postaci pożyczek i kredytów. We wszystkich analizowanych latach odnotowano spółdzielnie mleczarskie, które w strukturze finansowania nie wykazywały zobowiązań długoterminowych. W 2010 roku 14 jednostek nie posiadało w ogóle zobowiązań długoterminowych, 
natomiast w 2011 roku - 13 spółdzielni. W kolejnych latach liczba podmiotów bez zobowiązań długoterminowych ulegała zwiększeniu. W 25\% spółdzielni mleczarskich wskaźnik zadłużenia długoterminowego nie przekraczał $2 \%$, natomiast w połowie populacji wskaźnik ten osiągnął maksymalny pułap w 2012 roku 9,5\%. Maksymalny poziom zadłużenia długoterminowym kapitałem obcym wynosił $117,2 \%$ w 2014 roku. W badanych latach przeciętny udział zobowiązań długoterminowych w 75\% badanych spółdzielni mleczarskich wahał się w przedziale od 17,5\% do 24,5\%. W latach 2010-2014 wskaźnik zadłużenia długoterminowego przekraczał 50\% w co najmniej trzech spółdzielniach mleczarskich.

W tabeli 5 przedstawiono statystki opisowe zróżnicowania wskaźników sprawności działania spółdzielni mleczarskich w latach 2010-2014. Przeciętny wskaźnik cyklu zapasów w spółdzielniach mleczarskich kształtował się na zbliżonym poziomie we wszystkich latach i wyniósł od 18,4 dni do 19,6 dni. Minimalny czas odnowienia zapasów w badanych spółdzielniach wyniósł od 3 dni do 5 dni, natomiast maksymalny okres w którym zarządzający odnawiali zapasy wyniósł 93 dni w 2014 roku. Poziom wskaźnika cyklu zapasów charakteryzował się rozkładem prawo skośnym $\left(\bar{x}>Q_{2}\right)$, co oznaczało, że w ponad połowie badanych spółdzielni mleczarskich cykl ten był niższy od średniej z całej badanej populacji.

W analizowanych latach zarządzający spółdzielniami mleczarskimi inkasowali należności przeciętnie w terminie od 32 dni do 37 dni. W latach 2012-2014 najkrótszy termin uzyskania zapłaty za sprzedane produkty mleczarskie wynosił 8,9-9,9 dni. Może to świadczyć o tym, że zarządzający niektórymi spółdzielniami mleczarskimi nie kredytowali swoich kontrahentów, a jedynie stosowali tak zwany kredyt manipulacyjny ${ }^{6}$. Kredyt ten udzielany jest najczęściej od 3 do 7 dni, a termin kredytowania przeznaczony jest jedynie na dokonanie transakcji gotówkowej lub przelewu przez kontrahenta. W teorii kredyt manipulacyjny nie jest zaliczany do kredytu handlowego, który traktowany jest jako sprzedaż z odroczonym terminem płatności. Ponadto spółdzielnie te mogły stosować w transakcjach ze stałymi partnerami handlowymi jedynie odroczenie terminu zapłaty do 14 dni, czyli do terminu najbardziej preferowanego przez dawców kredytu handlowego. Osiągnięcie tak krótkiego czasu inkasowania należności mogło również wynikać z dość restrykcyjnego przestrzegania terminów płatności oraz stosowania okre-

\footnotetext{
${ }^{6}$ Kredyt manipulacyjny oznacza odroczenie terminu zapłaty, które wynika z niezbędnych i niemożliwych do uniknięcia czynności technicznych związanych z realizacją transakcji. Odroczenie zapłaty ma zatem charakter manipulacyjny wówczas, gdy data płatności wyznaczona jest w krótkim, kilkudniowym okresie po wykonaniu świadczenia. Okres ten jest przeznaczony w szczególności na przyjęcie dostawy przez odbiorcę i dokonanie czynności technicznych związanych z przekazaniem gotówki, tj. wystawieniem i złożeniem polecenia przelewu po uprzednim sprawdzeniu zgodności faktury ze złożonym zamówieniem i dostawą [Krzemińska 2009, s. 25].
} 
TABELA 5. Statystyki opisowe zróżnicowania wskaźników sprawności działania (dni)

\begin{tabular}{|l|c|c|c|c|c|c|c|c|c|}
\hline \multicolumn{2}{|l|}{ Wyszczególnienie } & \multicolumn{7}{|c|}{ Statystyki opisowe* } \\
\hline Zmienna & Lata & $\mathrm{x}_{\min }$ & $\overline{\mathrm{x}}$ & $\mathrm{x}_{\max }$ & $\mathrm{Q}_{1}$ & $\mathrm{Q}_{2}$ & $\mathrm{Q}_{3}$ & $\sigma$ & $\mathrm{V}$ \\
\hline \multirow{4}{*}{$\begin{array}{l}\text { Wskaźnik } \\
\text { cyklu } \\
\text { zapasów }\end{array}$} & 2010 & 5,0 & 18,6 & 78,7 & 11,4 & 16,8 & 21,0 & 11,9 & 63,9 \\
\cline { 2 - 11 } & 2011 & 4,5 & 19,6 & 73,5 & 11,6 & 18,0 & 23,4 & 12,3 & 62,5 \\
\cline { 2 - 11 } & 2012 & 4,3 & 18,4 & 83,5 & 12,2 & 17,5 & 20,9 & 11,2 & 60,8 \\
\cline { 2 - 11 } & 2013 & 4,4 & 18,4 & 40,5 & 11,9 & 17,3 & 24,5 & 9,1 & 49,6 \\
\cline { 2 - 11 } & 2014 & 2,7 & 19,1 & 93,1 & 10,4 & 16,2 & 22,6 & 14,2 & 74,6 \\
\hline \multirow{4}{*}{$\begin{array}{l}\text { Wskaźnik } \\
\text { cyklu }\end{array}$} & 2010 & 10,9 & 36,0 & 69,7 & 28,4 & 35,2 & 44,4 & 11,6 & 32,1 \\
\cline { 2 - 10 } & 2011 & 14,1 & 37,4 & 69,8 & 29,6 & 35,7 & 45,8 & 11,9 & 31,9 \\
\cline { 2 - 10 } & 2012 & 8,9 & 36,6 & 57,4 & 28,0 & 35,8 & 46,9 & 11,8 & 32,3 \\
\cline { 2 - 10 } & 2013 & 9,9 & 36,5 & 61,4 & 28,3 & 34,9 & 45,5 & 11,0 & 30,2 \\
\cline { 2 - 10 } & 2014 & 8,9 & 32,0 & 50,9 & 24,8 & 30,8 & 39,3 & 10,4 & 32,4 \\
\cline { 2 - 10 } & 2010 & 17,2 & 48,9 & 171,5 & 37,1 & 46,1 & 55,6 & 20,6 & 42,2 \\
\cline { 2 - 10 } $\begin{array}{l}\text { Wskaźnik } \\
\text { cyklu } \\
\text { zobowiązań }\end{array}$ & 2011 & 17,7 & 47,3 & 83,4 & 38,0 & 46,5 & 54,2 & 13,4 & 28,3 \\
\cline { 2 - 10 } & 2012 & 13,9 & 45,3 & 79,8 & 36,3 & 42,7 & 52,5 & 14,4 & 31,9 \\
\cline { 2 - 10 } & 2013 & 19,4 & 49,0 & 113,1 & 40,0 & 46,9 & 54,0 & 14,6 & 29,8 \\
\cline { 2 - 10 } & 2014 & 15,8 & 41,7 & 96,1 & 32,9 & 39,6 & 47,6 & 14,3 & 34,3 \\
\hline
\end{tabular}

*Statystyki opisowe: $\mathrm{x}_{\min }-$ minimum, $\mathrm{x}_{\max }-$ maksimum, $\overline{\mathrm{x}}$ - średnia arytmetyczna, $\mathrm{Q}_{1}-\mathrm{kwartyl} 1$, $\mathrm{Q}_{2}$ - kwartyl 2 (mediana), $\mathrm{Q}_{3}$ - kwartyl 3, $\sigma$ - odchylenie standardowe, $\mathrm{V}$ - współczynnik zmienności.

Źródło: opracowanie własne.

ślonych metod zabezpieczeń kredytu handlowego, a także odpowiednich sposobów windykowania tych należności.

W analizowanych latach $25 \%$ badanych spółdzielni mleczarskich inkasowało swoje wierzytelności w okresie nieprzekraczającym 30 dni (czyli jednego miesiąca), natomiast połowa tych jednostek uzyskiwała gotówkę za sprzedaż swoich wyrobów w okresie do 36 dni. W ciągu 47 dni swoje należności odzyskiwało 75\% badanych spółdzielni mleczarskich. Najdłuższy okres inkasowania należności przez zarządzających spółdzielniami mleczarskimi wynosił od 50 dni w 2014 roku do 70 dni w latach 2010-2011. Spośród przyjętych wskaźników sprawności, badane spółdzielnie mleczarskie pod względem długości cyklu należności były najbardziej jednorodne. Oznacza to, że współczynnik zmienności dla wskaźnika cyklu należności był najniższy. W latach 2010-2014 współczynnik ten wyniósł maksymalnie $32,4 \%$, podczas gdy dla pozostałych wskaźników kształtował się na poziomie $74,6 \%$ (dla cyklu zapasów) i 42,2\% (dla cyklu zobowiązań). Ponadto odchylenie od średniej dla całej populacji wynosiło maksymalnie 12 dni dla 
wskaźnika cyklu należności, podczas gdy odchylenie od średniej dla cyklu zapasów wyniosło 14,2 dni, natomiast dla cyklu zobowiązań maksymalnie 20,6 dni.

Wskaźnik cyklu zobowiązań $\mathrm{w}$ analizowanych latach wyniósł przeciętnie od 41,7 dni w 2014 roku do 49,0 dni w 2013 roku. Najkrótszy termin spłaty zobowiązań krótkoterminowych wynosił 14 dni w 2012 roku, natomiast najdłuższy okres niezbędny do uregulowania własnych długów wyniósł 172 dni w 2010 roku. Zarządzający w przypadku 25\% analizowanych spółdzielni mleczarskich potrzebowali na spłatę swoich zobowiązań co najmniej 33 dni w 2014 roku do 40 dni w 2013 roku. Połowa analizowanej grupy mieściła się przedziale od 40 dni do 47 dni, natomiast 75\% jednostek spłacało swoje zobowiązania po upływie od 48 dni do 56 dni w latach 2010-2014. Istotny z punktu widzenia zarządzających jest fakt możliwości wydłużania terminów płatności w latach lepszej koniunktury na rynku (2013 rok).

\section{WNIOSKI}

W pracy przedstawiono zróżnicowanie sytuacji finansowej spółdzielni mleczarskich w Polsce, za pomocą wskaźników płynności finansowej, skorygowanej rentowności, zadłużenia oraz sprawności działania.

W toku przeprowadzonych badań sformułowano następujące wnioski:

1. W badanym okresie zarządzający spółdzielniami mleczarskimi utrzymywali wskaźniki płynności finansowej na poziomie nie zagrażającym występowaniem zwiększonego ryzyka utraty zdolności do terminowego regulowania zobowiązań bieżących. Bez względu na koniunkturę gospodarczą na rynku, zarządzający w znacznej mierze zachowywali ostrożność w celu uniknięcia ryzyka, które mogło wpływać na zdolność do kontynuacji działania tych jednostek. Biorąc pod uwagę nie tylko powierzone mienie ale również szereg interesariuszy, zarządzający spółdzielniami mleczarskimi przyjmowali w znacznej mierze konserwatywne podejście do struktury majątku i źródeł jego finansowania.

2. Zróżnicowanie sytuacji finansowej spółdzielni mleczarskich było stosunkowo duże. Zarówno efektywność jak i struktura finansowania uzależniona była od skali i warunków prowadzonej działalności. Duże różnice w poziomie zadłużenia jak i skorygowanej rentowności prowadzonej działalności mogły oznaczać duże możliwości do dalszej konsolidacji jednostek.

3. Sytuacja finansowa spółdzielni mleczarskich mogła być determinowana koniunkturą rynkową. W spółdzielniach mleczarskich udziałowcami są dostawcy, którzy oczekują zbytu mleka krowiego bez względu na warunki rynkowe. Sytuacja ta mogła powodować okresy mniej efektywnej działalności w spółdzielniach mleczarskich. Mniejsze nastawienie na kreowanie zysku i wartości 
dla właścicieli spółdzielczej formy własności stwarza najlepsze możliwości realizacji stawianych celów.

\section{Spis literatury}

BARAN J. 2008: Efektywność techniczna a wyniki finansowe spółdzielni mleczarskich w latach 2003-2005. Zeszyty Naukowe Szkoły Głównej Gospodarstw Wiejskiego w Warszawie, Ekonomika i Organizacja Gospodarki Żywnościowej, nr 64, s. 101-112.

CHĄDRZYŃSKI M., Nowak M.M. 2014: Wybrane aspekty ekonomiczno-finansowe działalności spółdzielni mleczarskich. Roczniki Naukowe Stowarzyszenia Ekonomistów Rolnictwa i Agrobiznesu, t. XIV, z. 4, s. 68-73.

CHMIELEWSKA M., MĄDRA M. 2008: Optymalizacja struktury sprzedaży w spółdzielni mleczarskiej, Roczniki Nauk Rolniczych, Seria G, t. 95, z. 2, s. 60-67.

DOMAŃSKA T. 2016: Sytuacja finansowa spółdzielni mleczarskich o różnej pozycji kredytowej, Zarządzanie Finansami i Rachunkowość, nr 4/1, s. 59-71.

DWORNIAK J. 2010: Ekonomiczno-finansowe skutki zmian funduszu udziałowego w spółdzielniach mleczarskich, Wydawnictwo SGGW, Warszawa.

GUS 2016: Rocznik statystyczny rolnictwa.

KATA R. 2016: Spółdzielczość w Polsce na tle innych krajów Unii Europejskiej - stan i współczesne wyzwania. Roczniki Ekonomiczne Kujawsko-Pomorskiej Szkoły Wyższej w Bydgoszczy, nr 9, s. 67-86.

KRZEMIŃSKA D. 2009: Wiarygodność kontrahenta w kredycie kupieckim, Wydawnictwo Uniwersytetu Ekonomicznego w Poznaniu, Poznań.

PIETRZAK M. 2006: Efektywność finansowa spółdzielni mleczarskich - koncepcja oceny, Wydawnictwo SGGW, Warszawa.

PIETRZAK M. 2007: Skala spółdzielni mleczarskich a ich wyniki ekonomiczno-finansowe w latach 1999-2005, Roczniki Nauk Rolniczych, Seria G, t. 93, z. 2, s. 107-117.

PIETRZAK M. 2010: Klasyczne i dedykowane wskaźniki oceny efektywności spółdzielni mleczarskich na przykładzie uczestników IV Rankingu Forum Spółdzielczości Mleczarskiej, Roczniki Nauk Rolniczych, Seria G, t. 97, z. 4, s. 172-182.

SIERPIŃSKA M., JACHNA T. 2004: Ocena przedsiębiorstwa według standardów światowych, PWN, Warszawa.

Ustawa z dnia 16 września 1982 r. Prawo Spółdzielcze, Dz. U. Nr 30 poz. 210.

WASILEWSKI M., DWORNIAK J. 2007: Fundusz udziałowy a sytuacja finansowa spółdzielni mleczarskich. Roczniki Nauk Rolniczych, Seria G, t. 93, z. 2, s. 118-128.

ZUBA M., ZUBA J. 2011: Wpływ wielkości skupu mleka na rentowność wybranych spółdzielni mleczarskich w Polsce. Roczniki Naukowe Stowarzyszenia Ekonomistów Rolnictwa i Agrobiznesu, T XIII, Z 1, s. 490-494.

ZUBA M. 2009: Spółdzielnie mleczarskie trwałą formą agrobiznesu, Zeszyty Naukowe WSEI w Lublinie, seria Ekonomia, nr 1, s. 167-175. 


\section{THE DIFERENTATION OF FINANCIAL SITUATION IN DAIRY COOPERATIVES IN POLAND}

Abstract. The study presents diversification of the financial situation of the dairy cooperatives in Poland. In order to determine the financial situation of those entities, the rates of liquidity, adjusted profitability as well as indebtedness and operational efficiency were used. The research period covered the years from 2010 to 2014. Regardless of the economic situation on the market, the managers took special care in order to avoid risk that could affect the entity's ability to continue to operate. The diversification of the financial situation of the dairy cooperatives was relatively significant. Both effectiveness and financing structure were dependent on a scale and conditions of business.

Key word: liquidity, adjusted profitability, indebtedness, operational efficiency, dairy cooperative, financial situation 